\title{
KAJIAN BAHAYA KEBAKARAN HUTAN DI KABUPATEN NGANJUK
}

\section{FOREST FIRE HAZARD ZONATION ASSESSMENT IN NGANJUK DISTRICT}

\author{
Heru Sri Naryanto ${ }^{1}$ dan Wisyanto ${ }^{1}$ \\ ${ }^{1}$ Pusat Teknologi Reduksi Risiko Bencana (PTRRB), Kedeputian TPSA - Badan Pengkajian dan \\ Penerapan Teknologi (BPPT) \\ Gedung Geostech, Lantai 1, Kompleks Puspiptek Serpong, Tangerang Selatan \\ email: heru.naryanto@bppt.go.id
}

\begin{abstract}
The Nganjuk District is mostly planted by protection and production forests with a total area of 20,333 ha. Forest and land fires often occur in Nganjuk District, which causes economic and environmental losses. Forest and land fires often cause haze disasters that can disrupt the activities and health of surrounding communities. The forest and land fires hazard map is needed. Making a forest and land fires hazard map of Nganjuk District is carried out with consideration of various parameters, namely: rainfall, land use, altitude, and type of forest. Data analysis was carried out using spatial analysis with a scoring system of influential parameters and was classified into high hazard of forest and land fires, medium hazard of forest and land fires, and low hazard of forest and land fires. The biggest five sub-districts in Nganjuk District are included in the high zone of forest and land fires are sub-districts: Rejoso, Lengkong, Ngluyu, Gondang, and Jatikalen. Zoning maps of forest and land fire hazards in Nganjuk District are urgently needed in the framework of mitigation, adaptation and disaster management of forest and land fires, as well as sustainable development planning in Nganjuk District.
\end{abstract}

Keywords: Nganjuk, forest and land fires, hazard zone map, mitigation.

\begin{abstract}
ABSTRAK
Kawasan Kabupaten Nganjuk banyak ditumbuhi oleh hutan-hutan lindung dan produksi dengan luas total 20.333 ha. Kebakaran hutan dan lahan sering terjadi di Kabupaten Nganjuk, yang menyebabkan kerugian ekonomi dan lingkungan. Kebakaran hutan dan lahan seringkali menyebabkan bencana asap yang dapat mengganggu aktivitas dan kesehatan masyarakat sekitar. Peta zonasi bahaya kebakaran hutan dan lahan sangat diperlukan. Pembuatan peta bahaya kebakaran hutan dan lahan Kabupaten Nganjuk dilakukan dengan pertimbangan berbagai parameter, yaitu: curah hujan, tataguna lahan, ketinggian tempat, dan jenis hutan. Analisis data dilakukan dengan menggunakan analisis spasial dengan sistem skoring dari parameter yang berpengaruh, dan diklasifikasikan menjadi: bahaya kebakaran hutan dan lahan tinggi, bahaya kebakaran hutan dan lahan sedang, dan bahaya kebakaran hutan dan lahan rendah. Lima kecamatan terbesar di Kabupaten Nganjuk yang termasuk dalan zona bahaya kebakaran hutan dan lahan tinggi adalah kecamatan-kecamatan: Rejoso, Lengkong, Ngluyu, Gondang, dan Jatikalen. Peta zonasi bahaya kebakaran hutan dan lahan di Kabupaten Nganjuk sangat diperlukan dalam rangka mitigasi, adaptasi dan penanggulangan bencana kebakaran hutan dan lahan, serta perencanaan pembangunan berkelanjutan di Kabupaten Nganjuk.
\end{abstract}

Kata kunci: Nganjuk, kebakaran hutan dan lahan, peta zonasi bahaya, mitigasi.

I. PENDAHULUAN

\subsection{Gambaran Kebakaran Hutan dan Lahan}

Indonesia adalah negara kepulauan terbesar di dunia, yang mengalokasikan 63\% atau seluas 120,6 juta hektar daratannya, sebagai Kawasan Hutan, sedangkan sisanya 
sekitar $37 \%$ merupakan Areal Penggunaan Lain (APL). Disamping itu, sekitar 5,3 juta hektar dari perairan wilayah Indonesia telah ditetapkan sebagai Kawasan Konservasi Perairan yang pengelolaannya dimandatkan kepada Kementerian Lingkungan Hidup dan Kehutanan (KLHK, 2018).

Hutan tropika Indonesia telah dikenal di dunia sebagai hutan tropika terluas nomor tiga (3), setelah negara Brazil dan Zaire. Pemicu hilangnya hutan tropika Indonesia diantaranya adalah peristiwa kebakaran hutan. Dalam sejarah kebakaran hutan di Indonesia, kebakaran hutan yang terbesar terjadi pada tahun 1997/1998 yang mencapai luasan 9,7 juta ha lahan dengan luasan areal terbakar (Ismail \& Kamarubayana, 2017).

Kawasan Kabupaten Nganjuk banyak dtumbuhi oleh hutan. Menurut BPS Kabupaten Nganjuk (2014), luas hutan keseluruhan di Kabupaten Nganjuk adalah 20.333 ha, yang terdiri dari hutan lindung $(951,1$ ha) dan hutan produksi (19.381,9 ha). Selain itu, reboisasi hutan juga dilakukan pada areal seluas 619,5 ha.

Kebakaran hutan dan lahan adalah suatu keadaan di mana hutan dan lahan dilanda api, sehingga mengakibatkan kerusakan hutan dan lahan yang menimbulkan kerugian ekonomi dan atau nilai lingkungan. Kebakaran hutan dan lahan seringkali menyebabkan bencana asap yang dapat mengganggu aktivitas dan kesehatan masyarakat sekitar. Kebakaran terjadi karena terbakarnya belukar, limbah kayu, rumput, daun, dan ranting yang ada di permukaan tanah. Kebakaran permukaan merupakan awal kebakaran tajuk. Kebakaran tajuk menjalar cepat dari satu tajuk ke tajuk pohon lainnya.

Kebakaran hutan dan lahan memberikan dampak yang cukup besar bagi kerugian manusia baik material maupun imaterial. Pemerintah telah berupaya keras menyelesaikan permasalahan ini baik melalui dukungan kebijakan, dukungan kelembagaan, maupun dukungan pendanaan. Namun realitanya kejadian ini masih berulang sepanjang tahun (Supriyanto et al., 2018).

Dampak kebakaran hutan dan lahan yang menonjol adalah terjadinya kabut asap yang mengganggu kesehatan dan sistem transpotasi darat, laut, dan udara. Dampak kebakaran hutan terhadap produksi pertanian diduga tidak terlalu besar karena pembakaran dilakukan untuk penyiapan lahan, kecuali jika kebakaran mencapai lahan pertanian yang berproduksi.
Kebakaran hutan menghasilkan emisi karbon yang dilepaskan ke atmosfer.

Tipe vegetasi atau tutupan lahan merupakan bahan bakar pada saat terjadinya kebakaran hutan dan lahan. Mudah tidaknya vegetasi/tutupan lahan tersebut terbakar tergantung dari tingkat kepekaan tipe vegetasi atau tutupan lahan tersebut. Jika dalam keadaan tumbuhan sehat, maka sukar terbakar namun apabila dalam keadaan mati sangat mudah untuk terbakar. Serasah dan lapisan humus yang belum hancur merupakan lapisan bahan organik yang sudah mati terdiri dari daundaun, cabang-cabang pohon yang mati. Serasah mudah dikeringkan oleh udara sehingga mudah terbakar. Cabang-cabang pohon yang mati dan pohon yang masih berdiri di hutan merupakan bahan bakar yang mudah menyala dan bila terbakar api dapat berkobar tinggi. Sisa penebangan misalnya penebangan dalam penjarangan yang banyak meninggalkan sisa-sisa kayu, cabang, dan daun-daun (Sahardjo, 2003).

Ketinggian tempat dapat mempengaruhi tingkat kepekaan suatu vegetasi terhadap kebakaran, dimana ketinggian tempat berkorelasi dengan jenis atau tipe vegetasi yang tumbuh. Secara umum dataran rendah akan didominasi oleh penggunaan lahan semak belukar, pertanian lahan kering, rumput, savanna, sedangkan dataran sedang hingga tinggi umumnya didominasi oleh hutan dan pohon-pohon besar. Dari berbagai hasil penelitian yang telah dilakukan di berbagai tempat menunjukkan bahwa kebakaran hutan dan lahan sebagian besar terjadi pada ketinggian kurang dari 200 meter dpl $(<200 \mathrm{~m}$ dpl).

Curah hujan merupakan salah satu faktor yang penting dalam proses terjadinya kebakaran hutan dan lahan. Kondisi iklim terutama pada periode dimana curah hujannya rendah merupakan salah satu pendorong terjadinya kebakaran. Kerawanan terjadinya kebakaran hutan dan lahan tertinggi terjadi pada musim kemarau dimana curah hujan sangat rendah dan intensitas panas matahari tinggi. Kondisi ini pada umumnya terjadi antara bulan Juni hingga Oktober dan kadang pula terjadi pada bulan Mei sampai November. Kadar air bahan bakar berpengaruh sangat nyata dalam menentukan perilaku api pada kebakaran hutan. Kadar air menentukan kemudahan bahan bakar untuk menyala, kecepatan proses pembakaran, kecepatan penjalaran api dan kemudahan 
usaha pemadaman kebakaran (Adinugroho, et al., 2005).

Tujuan dari penelitian ini adalah untuk mendapatkan gambaran zonasi bahaya kebakaran hutan dan lahan di Kabupaten Nganjuk, yang nantinya bisa dipergunakan dalam mitigasi, adaptasi dan penanganan bencana serta perencanaan pembangunan.

\section{BAHAN DAN METODE}

\subsection{Bahan}

Untuk membuat zonasi bahaya kebakaran hutan dan lahan di Kabupaten Nganjuk, digunakan kontur rupabumi skala 1: 25.000 yang didapat dari BIG untuk analisis kelerengan. Untuk mendapatkan gambaran tipologi, jenis dan luasan hutan digunakan peta penggunaan lahan dari peta tata ruang Kabupaten Nganjuk yang diterbitkan oleh Bappeda Kabupaten Nganjuk (2017). Demikian juga untuk analisis curah hujan digunakan data curah hujan dari peta tata ruang tersebut. Lokasi penelitian dilakukan di Kabupaten Nganjuk, Provinsi Jawa Timur, pada bulan Maret-November 2019.

\subsection{Metode}

\subsubsection{Metode Umum}

Metode penelitian dalam pembuatan peta zonasi bahaya kebakaran hutan dan lahan di Kabupaten Nganjuk adalah sebagai berikut:

- Koordinasi dengan instansi terkait.

- Pengumpulan data sekunder.

- Pengumpulan data lapangan secara langsung.

Metode pengumpulan data merupakan teknik atau cara yang dilakukan untuk mengumpulkan data. Metode pengumpulan data yang biasa digunakan adalah angket, observasi, dan wawancara (Sugiyono, 2010). Sedangkan instrumen pengumpul data merupakan alat yang digunakan untuk mengumpulkan data. Karena berupa alat, maka instrumen dapat berupa lembar check list, kuesioner (angket terbuka/ tertutup), alat pengukur, kamera foto dan lainnya (Sekaran, 2006; Akhirianto \& Naryanto, 2016).

Pengolahan dan analisis data secara spasial/ kualitatif/ kuantitatif.
- Validasi data.

- Penyusunan peta zonasi bahaya kebakaran hutan dan lahan.

- Evaluasi data.

- Penyelesaian data.

\subsubsection{Analisis Spasial}

Analisis spasial dilakukan pada lokasi penelitian dengan tahapan proses sebagai berikut:

- Analisis peta kemiringan lereng dengan melakukan pengolahan data kontur rupabumi BIG skala 1: 25.000 melalui extension spatial analyst pada software ArcGIS 10.6.

- Analisis peta sub DAS dengan melakukan pengolahan data kontur rupabumi BIG Skala 1:25.000 melalui software Global Mapper.

- Analisis overlay data spasial infrastruktur jalan, sungai, sub DAS dan citra World Imagery dengan menggunakan software Global Mapper untuk mengetahui kondisi tata ruang (Naryanto et al., 2019).

- Analisis hutan dan lahan dengan menggunakan peta penggunaan lahan dari peta tata ruang Kabupaten Nganjuk (Bappeda Kabupaten Nganjuk, 2017), sehingga dapat diidentifikasi sebaran hutan dan lahan.

\subsubsection{Metode Pembuatan Peta Bahaya Kebakaran Hutan dan Lahan}

Metodologi yang digunakan dalam penyusunan peta bahaya kebakaran hutan dan lahan di Kabupaten Nganjuk dilakukan dengan pertimbangan berbagai parameter, yaitu: curah hujan, land cover, ketinggian tempat, dan jenis hutan (Naryanto et al., 2016).

Sebagai dasar utama dalam menentukan zonasi bahaya kebakaran hutan dan lahan di Kabupaten Nganjuk secara umum adalah dengan menggunakan Peraturan Kepala BNPB No. 02 Tahun 2012 tentang Pedoman Umum Pengkajian Risiko Bencana (BNPB, 2012).

Analisis dilakukan dengan menggunakan analisis spasial dengan sistem pembobotan dari parameter yang berpengaruh dan dari hasil analisis akan ditetapkan 3 (tiga) klasifikasi daerah rawan bahaya bencana kebakaran yaitu tingkat bahaya tinggi, tingkat bahaya sedang, dan tingkat bahaya rendah (Tabel 1). 
Tabel 1. Metodologi Pembuatan Peta Zonasi Bahaya Kebakaran Hutan dan Lahan (Sumber: Hasil Analisis Data, 2019)

\begin{tabular}{|c|c|c|c|c|c|}
\hline No & Parameter Berpengaruh & $\begin{array}{l}\text { Kelas Bahaya } \\
\text { Kebakaran } \\
\text { hutan tiap sub } \\
\text { Paramater }\end{array}$ & $\begin{array}{c}\text { Nilai } \\
\text { Bobot } \\
\text { Tiap sub } \\
\text { Parameter }\end{array}$ & $\begin{array}{l}\text { Nilai } \\
\text { Minimal }\end{array}$ & $\begin{array}{l}\text { Nilai } \\
\text { Maksimal }\end{array}$ \\
\hline I & \multicolumn{4}{|l|}{ Curah Hujan (25\%) } & \\
\hline $\mathrm{a}$ & $800-1.400 \mathrm{~mm}$ & 30 & 7,5 & & 7,5 \\
\hline$b$ & $1.400-1.900 \mathrm{~mm}$ & 25 & 6,25 & & \\
\hline c & $1.900-2.300 \mathrm{~mm}$ & 20 & 5 & & \\
\hline$d$ & $2.300-2.800 \mathrm{~mm}$ & 15 & 3,75 & & \\
\hline e & $2.800-3.700 \mathrm{~mm}$ & 10 & 2,5 & 2,5 & \\
\hline II & \multicolumn{4}{|l|}{ Land Cover (40\%) } & \\
\hline a & Hutan & 60 & 24 & & 24 \\
\hline $\mathrm{b}$ & Ladang/tegalan & 30 & 12 & & \\
\hline c & $\begin{array}{l}\text { Sawah irigasi, sawah tadah } \\
\text { hujan }\end{array}$ & 20 & 8 & & \\
\hline$d$ & $\begin{array}{l}\text { Permukiman, industri dan } \\
\text { pergudangan, peternakan } \\
\text { unggas, pertambangan, waduk, } \\
\text { sungai, embung }\end{array}$ & 10 & 4 & 4 & \\
\hline III & \multicolumn{4}{|l|}{ Ketinggian Tempat (20\%) } & \\
\hline$a$ & $35 m-100 m$ & 27 & 5,4 & & 5,4 \\
\hline $\mathrm{b}$ & $100 m-250 m$ & 22 & 4,4 & & \\
\hline C & $250 m-450 m$ & 17 & 3,4 & & \\
\hline$d$ & $450 m-750 m$ & 12 & 2,4 & & \\
\hline e & $750 m-1.150 m$ & 10 & 2 & & \\
\hline$f$ & $1.150 m-1.650 m$ & 7 & 1,4 & & \\
\hline$g$ & $>1.650 \mathrm{~m}$ & 5 & 1 & 1 & \\
\hline IV & Jenis Hutan (15\%) & & & & \\
\hline a & Hutan produksi & 65 & 9,75 & & 9,75 \\
\hline $\mathrm{b}$ & Hutan lindung/konservasi & 35 & 5,25 & 5,25 & \\
\hline & TOTAL & & & 12,75 & 46,65 \\
\hline
\end{tabular}

Dari hasi perhitungan tersebut, rentang untuk menentukan pembagian zonasi bencana kebakaran hutan dan lahan adalah :

Interval $=\underline{\text { Total Nilai Maks } .- \text { Total Nilai Min } .}$ 3

Inteval $=\frac{46,65-12,75}{3}=\frac{33,9}{3}=11,3$

- Interval untuk zonasi bahaya kebakaran hutan dan lahan rendah $=12,75-24,05$
- Interval untuk zonasi bahaya kebakaran hutan dan lahan sedang $=20,05-35,35$

- Interval untuk zonasi bahaya kebakaran hutan dan lahan tinggi $=35,35-46,65$ 


\section{DATA DAN PEMBAHASAN}

\subsection{Kebakaran Hutan dan Lahan di Kabupaten Nganjuk}

World Resources Institute Indonesia atau WRI Indonesia (2019) telah mengembangkan peta risiko kebakaran berdasarkan sistem penilaian bahaya kebakaran US Forest Service. Peta tersebut memprediksi risiko terjadinya dan penyebaran kebakaran di suatu area tertentu menggunakan data satelit yang mengukur temperatur, kelembaban, dan curah hujan. Metrik tersebut membantu mengestimasi kadar air serasah hutan (pohon dan bagian tumbuhtumbuhan yang telah mati), semakin kering serasah hutan, semakin tinggi pula risiko kebakarannya. Ditambah lagi ketika suatu wilayah berada dalam kondisi mudah terbakar, seperti pada saat musim El Nino tahun lalu, kebakaran dapat dengan cepat membesar.

Berdasarkan data peta kebakaran lahan dan hutan Indonesia dari WRI Indonesia (2019), wilayah Kabupaten Nganjuk termasuk kelas sedang. Sebagaimana diketahui ancaman bahaya kebakaran lahan dan hutan faktor yang mempengaruhi selain faktor iklim juga keberadaan atau ketersediaan bahan bakar yang tersimpan di lahan dan hutan tersebut. Biomassa berupa tanah organik/gambut dan bahan biomassa vegetasi merupakan sisi lain yang menjadi bahan pertimbangan sangat penting di mana pada area tersebut mempunyai ancaman terhadap bahaya kebakaran lahan dan hutan.

Wilayah Kabupaten Nganjuk memang tidak menampakkan hotspot seperti apa yang terjadi di dataran wilayah lain seperti di Sulawesi, Kalimantan, dan Sumatera, dimana di ketiga pulau tersebut memang terdapat banyak pengembangan perkebunan besar. Persiapan untuk bercocok tanaman baik tanaman pangan ataupun tanaman perkebunan juga disinyalir sebagai bagian pemicu kebakaran lahan dan hutan dalam rangka kegiatan pembukaan lahan (land clearing) baik oleh korporasi maupun oleh petani/masyarakat. Kejadian kebakaran lahan yang terjadi di wilayah Kabupaten Nganjuk secara umum juga untuk persiapan tanam yaitu kegiatan pembersihan lahan.

Menurut data dari Global Forest Watch Fires (2019) yang mendeteksi peringatan berdasarkan kejadian kebakaran dalam suatu area, memperlihatkan beberapa hotspot yang terjadi di Kabupaten Nganjuk pada tanggal 2-9 Juli 2019. Dalam durasi waktu yang hanya seminggu tersebut ternyata Kabupaten Nganjuk terdapat 2 kali kasus kebakaran hutan dan lahan yang termasuk cukup tinggi diantara kabupaten/kota di Provinsi Jawa Timur (Gambar 2).



Gambar 1. Peta Risiko Bahaya Kebakaran Lahan dan Hutan Indonesia tahun 2015-2016 (WRI Indonesia, 2019). 


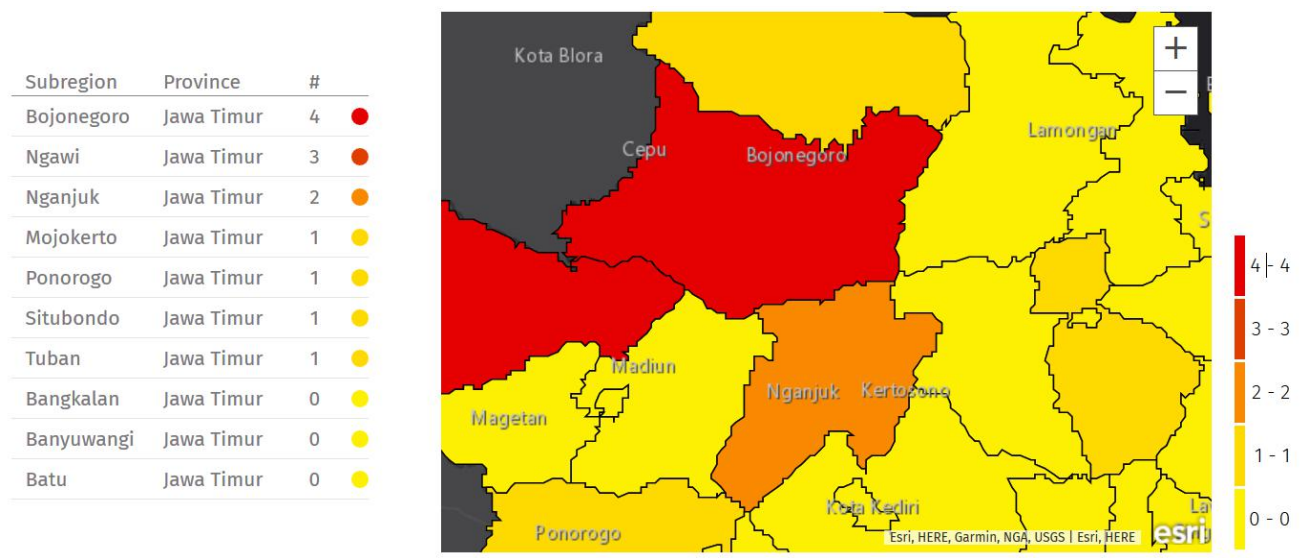

Gambar 2. Jumlah Peringatan Kebakaran Hutan dan Lahan di Kabupaten Nganjuk dan Sekitarnya Tangal 2-9 Juli 2019 (Global Forest Watch Fires, 2019).

\subsection{Peta Bahaya Kebakaran Hutan dan Lahan}

Jenis hutan yang yang ada di Kabupaten Nganjuk adalah hutan lindung dan hutan produksi. Dalam peta penggunaan lahan dibuat oleh Bappeda Kabupaten Nganjuk tahun 2017, hutan produksi banyak terdapat dalam daerah ladang atau tegalan. Hutan lindung milik Perhutani banyak terdapat di bagian selatan Kabupaten Nganjuk yang merupakan perbukitan terjal, yaitu di Kecamatan Sawahan dan Kecamatan Ngetos, serta di bagian utara yang meliputi kecamatan-kecamatan Ngluyu, Rejoso, Gondang, Lengkong dan Jatikalen. Sedangkan hutan produksi banyak terdapat di kecamatankecamatan Ngluyu, Rejoso, Gondang, Lengkong, Jatikalen, Wilangan, Berbek dan Bagor (Bappeda Kabupaten Nganjuk - BPPT, 2019; Naryanto \& Wisyanto, 2019).

Bahaya kebakaran hutan dan lahan di Kabupaten Nganjuk dibagi menjadi 3 zonasi, yaitu Zona Bahaya Tinggi, Zona Bahaya Sedang, dan Zona Bahaya Rendah. Bahaya kebakaran hutan dan lahan di Kabupaten Nganjuk seperti dijelaskan di bab metodologi.

Zona bahaya kebakaran hutan dan lahan tinggi sebagian besar terdapat di Kabupaten Nganjuk bagian utara dan sedikit di bagian selatan. Di bagian utara terdapat di kecamatankecamatan Ngluyu, Rejoso, Gondang, Lengkong, dan Jatikalen. Sementara di bagian selatan terdapat di Kecamatan Sawahan dan Kecamatan Ngetos.

Zona bahaya kebakaran hutan dan lahan sedang terdapat di bagian utara yaitu: kecamatan-kecamatan Ngluyu, Rejoso, Gondang, Lengkong, dan Jatikalen, di bagian barat di Kecamatan Wilangan, Kecamatan Berbek dan sebagian kecil Kecamatan Bagor. Sementara di bagian selatan terdapat di kecamatan-kecamatan: Sawahan, Ngetos dan Loceret.

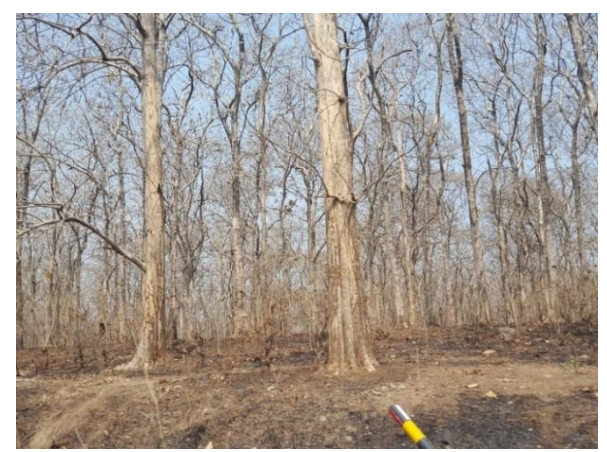

Gambar 3. Hutan Jati Milik Perhutani di Kecamatan Rejoso yang Mengalami Kerontokan Daun Pada Musim Kemarau, Mempunyai Potensi Sangat Tinggi untuk Terjadi Kebakaran.



Gambar 4. Penanggulangan Pemadaman Kebakaran Hutan di Hutan Milik Perhutani Kecamatan Wilangan pada Tahun 2019 (Sumber Gambar: Perhutani Kecamatan Wilangan, 2019) 




Gambar 5. Bekas-bekas Kebakaran Hutan

Perhutani yang Banyak Terjadi di Sepanjang Jalan Utama Wilangan-Sawahan.
Luas total zona bahaya kebakaran hutan dan lahan di Kabupaten Nganjuk seluas $8.509 .841,8$ ha, yang terdiri dari zona bahaya kebakaran hutan dan lahan tinggi 441.726,9 ha dan zona bahaya kebakaran hutan dan lahan sedang 346.595,9 ha (Gambar 6 dan Tabel 2).

Lima (5) kecamatan terbesar yang termasuk zona bahaya kebakaran hutan dan lahan tinggi di Kabupaten Nganjuk adalah kecamatankecamatan: Rejoso (123.151,3 ha), Lengkong (101.861,4 ha), Ngluyu (92.965,2 ha), Gondang (61.549,9 ha), Jatikalen (51.234,2 ha). Sedangkan lima kecamatan terbesar yang termasuk zona bahaya kebakaran hutan dan lahan sedang di Kabupaten Nganjuk adalah kecamatan-kecamatan: Wilangan (22.313,6 ha), Ngetos (46.339,2 ha), Sawahan (41.666,1 ha), Lengkong (31.910,3 ha), Gondang (25.156,6 ha) (Naryanto \& Wisyanto, 2019).

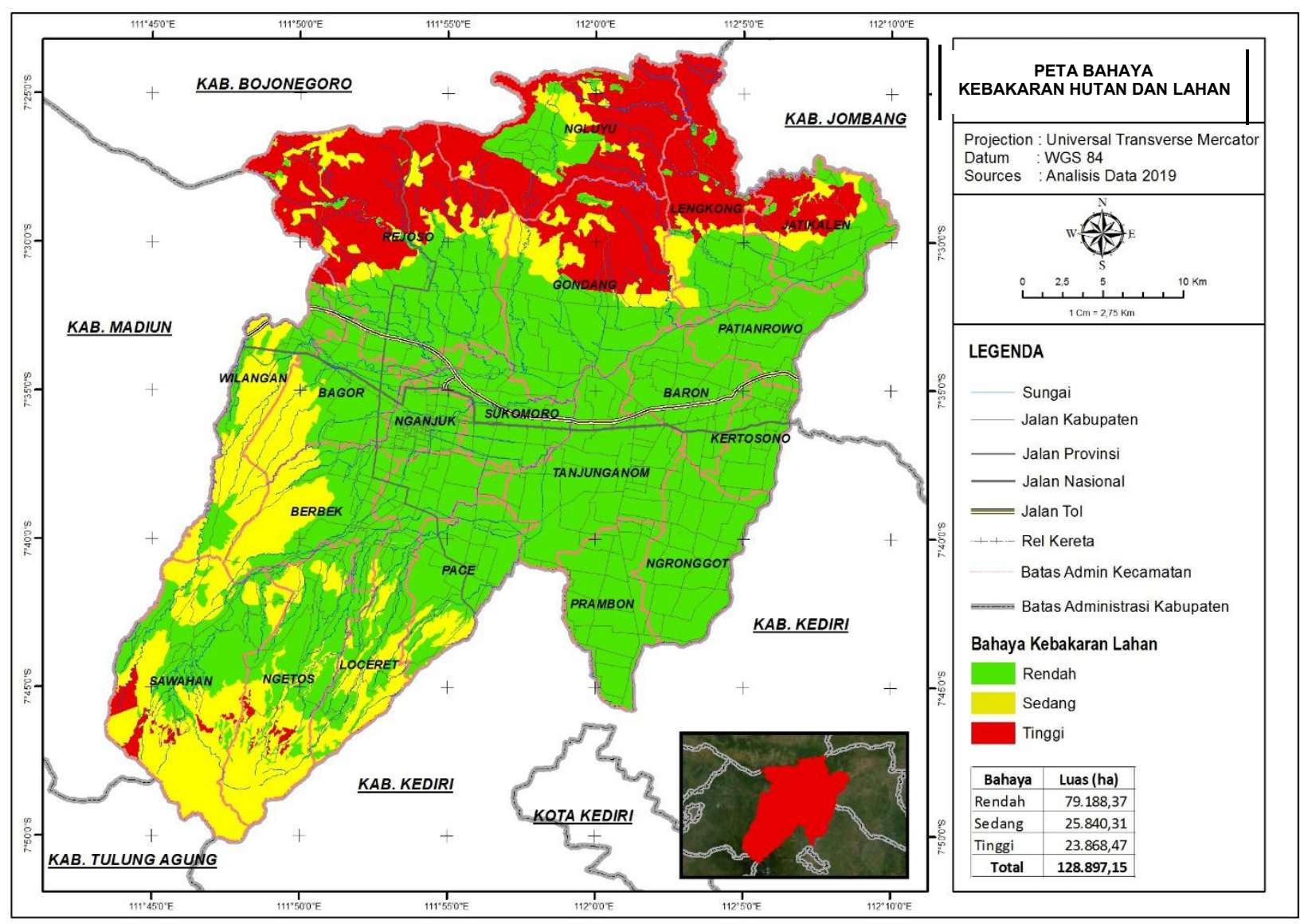

Gambar 6. Peta Zonasi Bahaya Kebakaran Hutan dan Lahan di Kabupaten Nganjuk (Sumber: Hasil Analisis Data, 2019) 
Tabel 2. Luas Zona Bahaya Kebakaran Hutan dan Lahan per Kecamatan di Kabupaten Nganjuk (Sumber: Hasil Analisis Data, 2019)

\begin{tabular}{|c|c|c|c|c|}
\hline \multirow[b]{2}{*}{ KECAMATAN } & \multicolumn{3}{|c|}{ ZONA (HA) } & \multirow{2}{*}{$\begin{array}{l}\text { LUAS } \\
\text { TOTAL }\end{array}$} \\
\hline & RENDAH & SEDANG & TINGGI & \\
\hline Bagor & $650.061,6$ & $18.714,7$ & $6.738,4$ & $675.514,8$ \\
\hline Baron & $348.004,3$ & & & $348.004,3$ \\
\hline Berbek & $579.259,3$ & $48.445,2$ & & $627.704,5$ \\
\hline Gondang & $599.552,9$ & $25.156,6$ & $61.549,9$ & $686.259,5$ \\
\hline Jatikalen & $415.479,9$ & $19.907,6$ & $51.234,2$ & $486.621,6$ \\
\hline Kertosono & $139.384,8$ & & & $139.384,8$ \\
\hline Lengkong & $478.026,7$ & $31.910,3$ & $101.861,4$ & $611.798,4$ \\
\hline Loceret & $662.509,1$ & $22.012,7$ & 236,1 & $684.757,9$ \\
\hline Nganjuk & $434.908,1$ & & & $434.908,1$ \\
\hline Ngetos & $81.302,1$ & $46.339,2$ & $1.257,2$ & $128.898,5$ \\
\hline Ngluyu & $2.8241,0$ & $24.373,5$ & $92.965,2$ & $145.579,7$ \\
\hline Ngronggot & $464.228,1$ & & & $464.228,1$ \\
\hline Pace & $544.554,8$ & $12.900,1$ & & $557.455,0$ \\
\hline Patianrowo & $295.203,9$ & 1,6 & & $295.205,5$ \\
\hline Prambon & $350.959,8$ & & & $350.959,8$ \\
\hline Rejoso & $528.222,1$ & $32.854,5$ & $123.151,3$ & $684.227,9$ \\
\hline Sawahan & $45.106,1$ & $41.666,1$ & $2.733,2$ & $89.505,4$ \\
\hline Sukomoro & $441.788,0$ & & & $441.788,0$ \\
\hline Tanjunganom & $517.410,0$ & & & $517.410,0$ \\
\hline Wilangan & $117.316,2$ & $22.313,6$ & & $139.629,8$ \\
\hline Luas total & $7.721 .518,9$ & $346.595,9$ & $441.726,9$ & $8.509 .841,8$ \\
\hline
\end{tabular}

\section{KESIMPULAN}

Penyusunan peta bahaya kebakaran hutan dan lahan Kabupaten Nganjuk dilakukan dengan parameter, yaitu curah hujan, tataguna lahan, ketinggian tempat, dan jenis hutan. Luas total zona bahaya kebakaran hutan dan lahan di Kabupaten Nganjuk seluas 8.509.841,8 ha, yang terdiri dari zona bahaya kebakaran hutan dan lahan tinggi 441.726,9 ha dan zona bahaya kebakaran hutan dan lahan sedang 346.595,8 ha. Lima kecamatan terbesar yang termasuk zona bahaya kebakaran hutan dan lahan tinggi di Kabupaten Nganjuk adalah kecamatankecamatan: Rejoso, Lengkong, Ngluyu, Gondang, dan Jatikalen.

Peta zonasi bahaya kebakaran hutan dan lahan di Kabupaten Nganjuk sangat diperlukan dalam rangka mitigasi, adaptasi dan penanganan bencana kebakaran hutan dan lahan serta perencanaan pembangunan dengan memprioritaskan pada zona bahaya tinggi.
Untuk melengkapi data maka perlu dibuat peta kerentanan dan peta risiko, untuk mendapatkan gambaran risiko masyarakat, sehingga prioritas penanggulangan bencana bisa lebih baik lagi.

\section{PERSANTUNAN}

Penulis mengucapkan terima kasih kepada Ir. Eko Widi Santoso MSi. (Direktur PTRRBBPPT), Bpk. Nur Hidayat, ST, MSi. (BPPT), Kepala Bappeda Kab. Nganjuk dan Bpk. Eko Wahyudi, (Bappeda Kab. Nganjuk). Ucapan terima kasih juga penulis sampaikan kepada rekan-rekan BPPT: Qoriatu Zahro, SSi, MSc., Ir. Hasmana Soewandita, MSi., dan Dyah Nursita Utami, SSi, sebagai bagian dari tim yang banyak membantu selama survei di lapangan, diskusi dan analisis data. Penelitian ini merupakan kerjasama penelitian antara PTRRB- BPPT dan Bappeda Kabupaten Nganjuk. 


\section{DAFTAR PUSTAKA}

Adinugroho, W. C., I N.N. Suryadiputra, B.H. Saharjo dan L. Siboro. 2005. Panduan Pengendalian Kebakaran Hutan dan Lahan Gambut. Proyek Climate Change, Forests and Peatlands in Indonesia.Wetlands International - Indonesia Programme dan Wildlife Habitat Canada. Bogor. Indonesia. 179 hal

Akhirianto, N.A. dan H.S. Naryanto. 2016. Kajian Kapasitas dan Persepsi Masyarakat Pangalengan Terhadap Bencana Tanah Longsor. Jurnal Riset Kebencanaan Indonesia, 2(2): 117-126.

Bappeda Kabupaten Nganjuk - BPPT. 2019. Studi Ex Lokasi Tambang Dalam Upaya Penciptaan Ektensifikasi Pertanian (Investigasi Potensi Cadangan Minyak dan Gas Di Kabupaten Nganjuk dan Potensi Bencananya), Laporan, tidak diterbitkan.

Bappeda Kabupaten Nganjuk, 2017, Tata Ruang Wilayah Kabupaten Nganjuk

BNPB. 2012. Peraturan Kepala Badan Nasional Penanggulangan Bencana Nomor 02 tahun 2012 Tentang Pedoman Umum Pengkajian Risiko Bencana.

BPS Kabupaten Nganjuk. 2014. Nganjuk dalam Angka.

Global Forest Watch Fires. 2019. Fire Report, Fiew Fire Statistics for Any Country. [terhubung berkala]. http://fires.globalforestwatch.org/home/.

KLHK. 2018. Status Hutan dan Kehutanan Indonesia 2018. Kementerian Lingkungan Hidup dan Kehutanan Republik Indonesia, 220 hal.

Naryanto, H.S, F. Prawiradisastra, A. Kristijono, dan D. Ganesha. 2019. Penataan Kawasan Pasca Bencana Tanah Longsor di Puncak Pass, Kecamatan Cipanas, Kabupaten Cianjur Tanggal 28 Maret 2018. Jurnal Pengelolaan Sumber Daya Alam dan Lingkungan, $\quad 9(1)$ : 100-104, http://dx.doi.org/10.29244/jpsl.9.1.\%15p

Naryanto, H.S dan Wisyanto. 2019. Pemetaan Zonasi Bahaya Gempa, Banjir, Kekeringan dan Kebakaran Hutan dan Lahan di Kabupaten Nganjuk, PTRRB-BPPT, Laporan, tidak diterbitkan.

Naryanto, H.S., H. Suwandita dan A. Pratama. 2016. Potensi Bencana di Kabupaten Banggai Laut. BPBD Kabupaten Banggai Laut - PTRRB-BPPT, Laporan, tidak diterbitkan.
Perhutani Kecamatan Wilangan. 2019. Dokumentasi Foto-Foto Penanggulangan Pemadaman Kebakaran Hutan di Hutan Perhutani Kecamatan Wilangan pada Tahun 2019.

Sahardjo, B.H. 2003. Pengendalian Kebakaran Hutan dan Lahan yang Lestari Perlukah Dilakukan. Laboratorium Kebakaran Hutan, Departemen Silvikultur, Fakultas Kehutanan, Institut Pertanian Bogor (IPB), Bogor.

Sekaran, U. 2006. Metodologi Penelitian Untuk Bisnis, Edisi Keempat.Jakarta: Penerbit Salemba Empat.

Sugiyono. 2010. Metode Penelitian (Pendekatan Kuantitatif, Kualitatif dan R\&D), Alfabetha, Bandung.

Supriyanto, Syarifudin, Ardi. 2018. Analisis Kebijakan Pencegahan dan Pengendalian Kebakaran Hutan dan Lahan di Provinsi Jambi. Jurnal Pembangunan Berkelanjutan, 1(1): 2622-2302.

World Resources Institute Indonesia (WRI Indonesia). 2019. Kebakaran Lahan dan Hutan Indonesia Tahun 2015-2016. [terhubung berkala]. http://www.wriindonesia.org/).

Ismail, Z. dan L. Kamarubayana. 2017. Studi Pengendalian Kebakaran Hutan di Wilayah Kelurahan Merdeka Kecamatan Samboja Kalimantan Timur. Jurnal Agrifor, XVI(1): 141-150. 